\title{
EFFECTS OF VIRTUALITY ON EMPLOYEE PERFORMANCE AND COMMITMENT: A RESEARCH
}

\author{
SANALLIĞIN ÇALIŞAN PERFORMANSI VE BAĞLILIĞI \\ ÜZERINNDEKİ ETKİLERİ: BİR ARAŞTIRMA
}

Zeynep BAYSAL*

Barış BARAZ ${ }^{* *}$

\begin{abstract}
In the modern business world, due to the impact of technological advancements and globalisation, organisations are obliged to keep up with the change in order to seize new opportunities they encounter and overcome the obstacles in their way. Concepts of virtuality and virtual organisations are among these concepts which surfaced as a result of these changes. All white-collar employees have a certain degree of virtuality and the fact that organisations are taking rapid steps towards virtualisation makes this topic a significant field of research. The aim of this study is to examine the relationship between the perceived degree of virtuality of organisations and the psycho-social performance and organisational commitment of employees. As a result, while a positive significant relationship was found between the degree of virtuality and psycho-social performance, while there was no relationship identified with organisational commitment. Moreover, according to a sub-scale about employees' individual propensity for virtuality, it was pointed out that virtual workers are happy with their conditions and are willing to continue to work the same way.
\end{abstract}

Keywords: Virtuality, Virtual Organisations, Psycho-social Performance, Organisational Commitment

Öz

Modern iş dünyasında, teknolojik gelişmelerin ve küreselleşmenin de etkisiyle örgütler karşılaştıkları yeni fırsatları değerlendirmek ve önlerine çıkan zorlukların üstesinden gelebilmek için değişimlere ayak uydurmak zorundadırlar. Sanallık ve sanal örgüt kavramları da bu değişimler sonucunda ortaya çıkan kavramlardandır. Beyaz yakalı çalışanların tamamı belirli bir düzeyde sanallığa sahiptir ve örgütlerin sanallaşma yolunda hızlı adımlarla ilerlemesi bu konunun önemli bir araştırma alanı haline gelmesini sağlamaktadır. Bu çalışmanın amacı, örgütlerin algılanan sanallık düzeyi ile çalışanların psiko-sosyal

* Anadolu University, Institute of Social Sciences, Department of Management and Organisation, zeynepalkin@anadolu.edu.tr

** Anadolu University, Faculty of Open Education, Department of Economic and Administrative Sciences, bbaraz@gmail.com 
performansları ve örgütsel bağlılıkları arasındaki ilişkinin incelenmesidir. Çalışmanın sonucunda sanallık düzeyi ile psiko-sosyal performans arasında pozitif bir ilişkiye rastlanırken, örgütsel bağlllık ile anlamlı bir ilişki saptanmamıştır. Ayrıca bir diğer destekleyici ölçek sonuçlarına göre de sanal çalışanların durumlarından memnun oldukları ve bu düzende devam etmek istedikleri sonucuna ulaşılmıştır.

Anahtar Sözcükler: Sanallık, Sanal Örgütler, Psiko-Sosyal Performans, Örgütsel Bağlllık

\section{Introduction}

Due to the rapidly changing and evolving circumstances of today's world, every day new terms and concepts appear in daily lives of individuals. Particularly in the business world, thanks to various factors such as the technology, globalisation and mobilisation, organisations, working styles and conditions of competition face significant changes. These developments bring along new business models, concepts and terms, one of which is virtualisation.

Although the word "virtual" has been used in various contexts for a long time, it is regarded as a relatively newer concept in the business world. Since the time the Internet was invented and presented to the public use, bringing the businesses to the virtual dimension has been a business opportunity captured by many. However, it has only been discovered later that, virtuality does not only offer an easier and cheaper way to reach the customers, but also provides remarkable advantages to the organisations and their employees. Similar to the way it provides access to distant customers; it can also make it possible for employees of an organisation to work from a distance.

It is possible to link the rise of virtual organisations to the advancements in the technology. While the technologies such as fax and telephone brought freedom to employees in terms of their dependency on brick and mortar offices, it was the wide use of Internet which opened a new era for organisations. The more the technology allowed people to do their work without being obliged to go to an office, the more employees became aware of the advantages of virtual work structures. Also, electronic communication technologies allowed a faster movement towards a new society which is based on service provision rather than being dependent on manufacturing of products (Fulk and DeSanctis, 1995) which resulted in more virtuality in organisational structures. In the context of this study, virtual organisations are referred as the structures where employees communicate with each other via information and communication technologies and it is suggested that it is possible to measure the degree of this overall contextual virtuality.

As the virtual organisations become increasingly more popular, it has become an intriguing field of research whether the advantages of this type of employment outweighs its disadvantages or vice versa. While employers realised that this new type of organisations allowed their employees to work from distance, work faster than traditional methods by using technology and work more by being able to work from any place with Internet and telephone access (Lojeski, 2010); employees 
realised that they were able to work from different time zones and geographic distances and to more people by working faster, cheaper and with less effort (Benton, 2012).

In the context of this study, the factors that have been examined are the psycho-social performance and the organisational commitment of employees. Psycho-social performance, which is the first dependent variable of the research, is defined based on the study conducted by Schmidt et. al. (2008) as the factors which directly and indirectly shape individuals' behaviours within the organisation. These factors are categorised into three dimensions. First of these three dimensions is orientation, which refers to employees having role clarity and knowing where to find the sources required to do their job; second is motivation, which refers to external or internal force which encourages the employee to work; and the third is identification, which refers to the feeling of employees that they belong in the organisation. Other dependent variable of the research is determined as the feeling of commitment felt by employees towards the organisation they work for, also known as organisational commitment, which has been defined by Meyer and Allen (1993) consisting of three dimensions as affective commitment, normative commitment and continuance commitment. According to this research, which is one of the most frequently cited studies in the field of organisational commitment, affective commitment refers to the willingness of the employee to stay in the organisation, whereas the normative commitment refers to his/her feeling of obligation and continuance commitment refers to his/her need to stay in the organisation.

The aim of this study is to identify the relationship between the overall degree of virtuality of organisations as perceived by employees and their psycho-social performance and organisational commitment. To that end, first a literature review will be provided on the concepts of virtuality as well as the results of previous studies exploring its relationship with other dependent variables. Afterwards the research conducted in this regard will be discussed in detail.

\section{Literature Review}

Virtuality is a complex concept perceived differently on various dimensions. While the term "virtual organisation" may refer to e-commerce companies for some, it may also mean the companies which solely operate on the Internet without any physical existence for others. Drawing on the definitions from the literature, it is possible to define virtual organisations as structures where people connected to each other by a long-term interest or objective provide products or services as independent from traditional physical locations while communicating and coordinating through telecommunication technologies and benefiting from their facilitating advantages (Kirel, 2007; Norton and Smith, 1997; Ahuja and Carley, 1998). Therefore the concept of virtual organisations is limited to this scope in this study.

The motive behind the appearance of virtual organisations is summarised under four headings as financial reasons, geographical diversity, faster opportunities for marketing and pressures from global markets and economy (Garton and Wegryn, 2006). The combination 
of all these factors can be regarded as the basis on which virtual organisations were established. Benefiting from all the advantages provided by these factors and encouraged by the challenges, organisations can use virtuality to gain competitive advantage. However, virtuality should not be regarded as the target but a strategic option which should only be preferred when after through analyses it is determined that it will meet the needs of the organisation and its customers better than a traditional organisational structure (Warner and Witzel, 2004). In other words, while providing various advantages; virtual organisational structures may not suit all types of organisations.

Although virtual organisations are becoming increasingly more common, in terms of research, it is still difficult to determine or measure the level of virtuality in an organisation. One of the tools developed for this purpose is the questionnaire created by Schmidt et. al. (2008), which was used in this study for measuring Overall Contextual Virtuality. This scale consists of the dimensions of degree of physical separation, degree of non-virtuality, degree of quantitative virtuality and degree of qualitative virtuality, which are mainly shaped based on the use of information and communication technologies and physical contact among employees. Similarly, according to another research conducted by Daniels et. al. (1999), virtual organisations should be evaluated based on five factors as the location, ICT usage, knowledge intensity, intra-organisational contact and extra-organisational contact. The nature and scope of these variables can be used for determining the degree of virtuality in an organisation.

Virtuality is a concept often studied in relationship with other dependent variables. It is known to have substantial impact on organisational structures and how organisations perform, therefore most of the studies conducted in this field focus not only on the concept of virtuality but also on its effects on other organisational variables. Some of these studies are explored in the following section.

\section{Previous Research}

Virtual organisations have been in the focus of the researchers in the field of social and administrative sciences for quite some time. It is appealing for researchers to examine this new type of employment and investigate its advantages and disadvantages on the dynamics of organisations, employers and employees. One of these studies is the one conducted by Schmidt et. al.(2008), which also forms the basis of the questionnaire used for this study. According to the study conducted by Schmidt et. al., there was no significant relationship found between the degree of virtuality and economic performance, but it was pointed out that virtuality had a positive effect on motivation and identification, whereas it was found out that the opposite applied for orientation. Although the questionnaire developed by Schmidt et. al. included a scale on economic performance, since it was limited to personal and team performance and was based on the declaration by employees, it was removed from the tool.

There are also other studies conducted on the relationship between virtuality and dimensions of psycho-social performance. For instance, another study conducted by comparing virtual 
organisations to traditional organisations (Merkevicius and Uturyte-Vrubliauskiene, 2008) demonstrated that orientation and role clarity is positively related to the degree of virtuality. Other two studies on motivation (Oflazer Mirap, 2004; Afgün, 2006) also indicated that there is a positive relationship between the degree of virtuality and motivation. A study conducted by Wiesenfeld et. al. (1999) also reveals the positive relationship between virtuality and identification.

In the scope of this study, another relevant term is employees' individual propensity for virtuality, which is basically their willingness to continue working in virtual organisation structures. There are also studies conducted on other psycho-social performance indicators which affect their willingness such as, work satisfaction (Webster and Wong, 2008; TinyPulse, 2015), communication among employees (Akkirman and Harris, 2005) and work coherence (Afgün, 2006) and they are also determined to be positively related to the degree of virtuality. On the other hand, socialisation (Oflazer Mirap, 2004; TinyPulse, 2015) is found out to have a negative relationship with virtuality. And finally, the study conducted by Afgün (2006) also indicates that there is no significant relationship between virtuality and the perception of organisational performance.

Studies show different results regarding the other dependent variable of the study, which is organisational commitment. There are studies which indicate that there is no significant relationship between the degree of virtuality and organisational commitment (Toglaw, 2006), whereas there are also others which indicate the opposite (Golden and Veiga, 2008; Golden, 2006; Burman and Shastri, 2013). In addition, the study conducted by Toglaw (2006) also indicates that there is a positive relationship between the degree of virtuality and occupational commitment. Abovementioned studies found in the literature on this topic are summarised in the list below:

Table I. Summary table for the studies from the literature

\begin{tabular}{l|l|l|l}
\hline & & $\begin{array}{l}\text { Significant } \\
\text { Relationship }\end{array}$ & Number of Studies and Years \\
\hline Degree of Virtuality & Dependent Variable & No & $1(2008)$ \\
& Oconomic Performance & Yes $(+,-)$ & $2(2008,2008)$ \\
& Orientation & Yes $(+)$ & $3(2008,2004,2006)$ \\
& Motivation & Yes $(+)$ & $2(2008,1999)$ \\
& Identification & Yes $(+)$ & $2(2004,2015)$ \\
& Socialisation & Yes $(+)$ & $1(2008,2015)$ \\
& Work Satisfaction & Yes $(+)$ & $1(2006)$ \\
& Communication Among Employees & $1(2006)$ \\
& Work Coherence & Yes $(+)$ & \\
& Perception of Organisational & No & $1(2006)$ \\
& Performance & No & $3(2006,2006,2013)$ \\
& Organisational Commitment & Yes $(+,-)$ & $1(2006)$ \\
\hline
\end{tabular}

As is seen, the effect of virtuality has been the main topic in a number of studies and the results indicate significant conclusions. While the relationship between the degree of virtuality and 
psycho-social performance factors (orientation, motivation, identification, socialisation etc.) has been determined to be significant and mostly positive, there are conflicting results in terms of the relationship between the degree of virtuality and commitment. In the light of these studies, hypotheses were developed and tested in order to further examine the relationship between these variables. In the following part, detailed explanations are provided on this study.

\section{Methods}

In line with virtual organisations becoming increasingly more prominent in the business world, the need arises for investigating their impact on employees. In the scope of this study, a research was conducted in order to identify the relationship between the overall contextual virtuality and the psycho-social performance and organisational commitment of employees. To that end, a questionnaire study was carried out and the results were analysed via the SPSS v22.0 software.

\section{Hypotheses, Research Framework and Scales}

The questionnaire developed for this study was based on two different works by different researchers. It is believed that, since these questionnaires were applied before in different contexts, it contributes to the reliability of the study. The overall contextual virtuality and psychosocial performance scales were obtained from the study "Virtuality in Organizational Team Environments: Concept, Measurement and Effects in the Context of Sustainable Management" conducted by Schmidt et. al. (2008) and the organisational commitment scale was developed by Meyer and Allen (1993) in their work titled "Commitment to Organizations and Occupations: Extension and Test of a Three-Component Conceptualization". Both scales are applicable scales with usable reliability scores. While the first scale by Schmidt et. al. (2008) is known to have been applied successfully in only one study, the scale developed by Meyer and Allen (1993) is one of the most commonly used scales in its field. These scales were adapted and translated and turned into a single questionnaire to be used for this study. Consent was taken personally from C. Schmidt via e-mail and it is stated by the authors of the organisational commitment scale that it is open for use only for academic purposes.

In the light of the literature review, five hypotheses were developed for this study. These hypotheses are listed below together with their alternative hypotheses: 
Table 2. Hypotheses of the research

\begin{tabular}{|c|c|}
\hline \multirow{2}{*}{ H1 } & $\begin{array}{l}\mathrm{H} 1_{0} \text { : Overall Contextual Virtuality does not vary depending on the organisational variables (organisation } \\
\text { size, sector, team size). }\end{array}$ \\
\hline & $\begin{array}{l}\mathrm{H}_{1} \text { : Overall Contextual Virtuality varies depending on the organisational variables (organisation size, } \\
\text { sector, team size). }\end{array}$ \\
\hline \multirow{2}{*}{$\mathrm{H} 2$} & $\begin{array}{l}\mathrm{H} 2_{2} \text { : Employees' Individual Propensity for Virtuality does not vary depending on personal variables (gender, } \\
\text { level of education, being a manager) and organisational variables (organisation size, sector, team size). }\end{array}$ \\
\hline & $\begin{array}{l}\text { H2: Employees' Individual Propensity for Virtuality varies depending on personal variables (gender, level } \\
\text { of education, being a manager) and organisational variables (organisation size, sector, team size). }\end{array}$ \\
\hline \multirow{2}{*}{ H3 } & $\begin{array}{l}\text { H3 : There is no significant relationship between the Overall Contextual Virtuality and employees' } \\
\text { Individual Propensity for Virtuality. }\end{array}$ \\
\hline & $\begin{array}{l}\text { H3: There is a significant relationship between the Overall Contextual Virtuality and employees' Individual } \\
\text { Propensity for Virtuality. }\end{array}$ \\
\hline \multirow{2}{*}{ H4 } & $\begin{array}{l}\text { H4 }{ }_{0} \text { : There is no significant relationship between the Overall Contextual Virtuality and employees' Psycho- } \\
\text { Social Performance. }\end{array}$ \\
\hline & $\begin{array}{l}\text { H4: There is a significant relationship between the Overall Contextual Virtuality and employees' Psycho- } \\
\text { Social Performance. }\end{array}$ \\
\hline \multirow{2}{*}{ H5 } & $\begin{array}{l}\text { H5: There is no significant relationship between the Overall Contextual Virtuality and employees' } \\
\text { Organisational Commitment. }\end{array}$ \\
\hline & $\begin{array}{l}\text { H5: There is a significant relationship between the Overall Contextual Virtuality and employees' } \\
\text { Organisational Commitment. }\end{array}$ \\
\hline
\end{tabular}

While the first two hypotheses were tested via ANOVA tests, other three were tested via regression analyses. Hypotheses 4 and 5 provide the actual answers for the research questions, whereas hypothesis 3 gives additional supporting information on the willingness of virtual workers to work in virtual settings. Research framework for the study is summarized in the research model below:

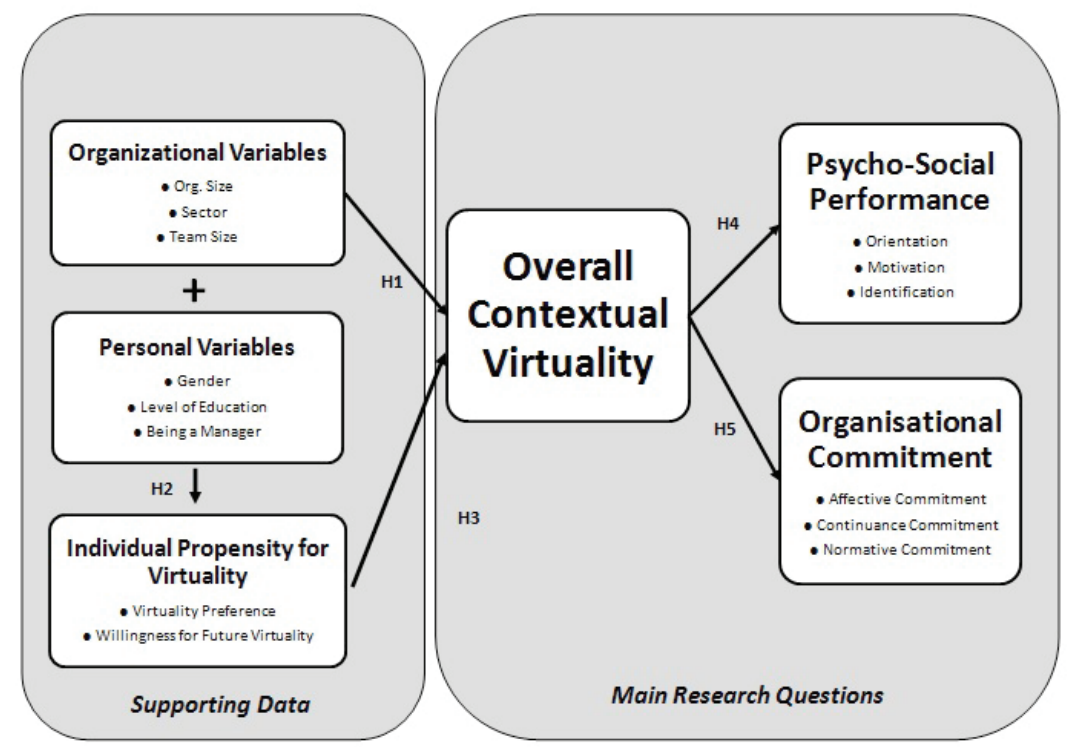

Figure I. Research framework 
As mentioned above, the questionnaire for this study was developed based on two different studies. Series of questions for demographic and organisational information were added in order to demonstrate the characteristics of the sample who participated in the study. The questions comprising the final variables are listed below:

Table 3. Scales in the questionnaire

\begin{tabular}{|c|c|c|}
\hline Dimension & Scale & Number of Questions \\
\hline \multirow{5}{*}{ Demographic Data } & City of residence & 1 \\
\hline & Location of the workplace & 1 \\
\hline & Age & 1 \\
\hline & Gender & 1 \\
\hline & Level of education & 1 \\
\hline \multirow{4}{*}{ Organisational Data } & Position/title & 1 \\
\hline & Organisation size & 1 \\
\hline & Sector & 1 \\
\hline & Team size & 1 \\
\hline \multirow{4}{*}{ Overall Contextual Virtuality (OCV) } & Degree of physical separation & 6 \\
\hline & Degree of non-virtuality & 8 \\
\hline & Degree of quantitative virtuality & 11 \\
\hline & Degree of qualitative virtuality & 4 \\
\hline \multirow{2}{*}{ Individual Propensity for Virtuality (IPV) } & Virtuality preference & 1 \\
\hline & Willingness for future virtuality & 1 \\
\hline \multirow{6}{*}{ Psycho-Social Performance (PSP) } & Orientation & 6 \\
\hline & Internal motivation & 3 \\
\hline & External motivation & 2 \\
\hline & Identification & 4 \\
\hline & Organisational satisfaction & 1 \\
\hline & Trust & 1 \\
\hline \multirow{3}{*}{ Organisational Commitment (OC) } & Affective commitment & 6 \\
\hline & Continuance commitment & 6 \\
\hline & Normative commitment & 6 \\
\hline Total number of questions & & 75 \\
\hline
\end{tabular}

Reliability of scales were tested via using the Cronbach's Alpha value and the results are provided below:

Table 4. Reliability of scales

\begin{tabular}{llll}
\hline Definition & Number of questions & Cronbach's Alpha & Usability \\
\hline Overall level of orientation & 6 &, 870 & Adequate \\
Overall level of internal motivation & 3 &, 641 & Usable \\
Overall level of external motivation & 2 &, 768 & Adequate \\
Overall level of identification & 4 &, 919 & Adequate \\
Overall level of affective commitment & 6 &, 706 & Adequate \\
Overall level of continuance commitment & 6 &, 747 & Adequate \\
Overall level of normative commitment & 6 &, 724 & Adequate \\
\hline
\end{tabular}




\section{Sample}

One of the limitations of the study was the difficulty in determining the universe for the study and therefore calculating the sample size. Due to the misconceptions regarding the definition of virtual organisations together with the fact that such organisations are becoming popular only recently, the study was not limited to only a company or a sector. Criterion sampling was used as the sampling method and participants were selected according to the criteria that they have some degree of virtuality. Therefore various companies from different sectors in Turkey were approached for the questionnaire study and a total number of 116 employees participated in the questionnaire. 5 of the forms were removed due to missing answers and therefore the analyses were conducted on a sample of 111 participants. The minimum sample size required for the regression analyses was calculated as 108 by using the software developed by Soper (2016). Detailed calculations and formulas can be found on the webpage.

Distribution of the participants based on their overall contextual virtuality is provided below:

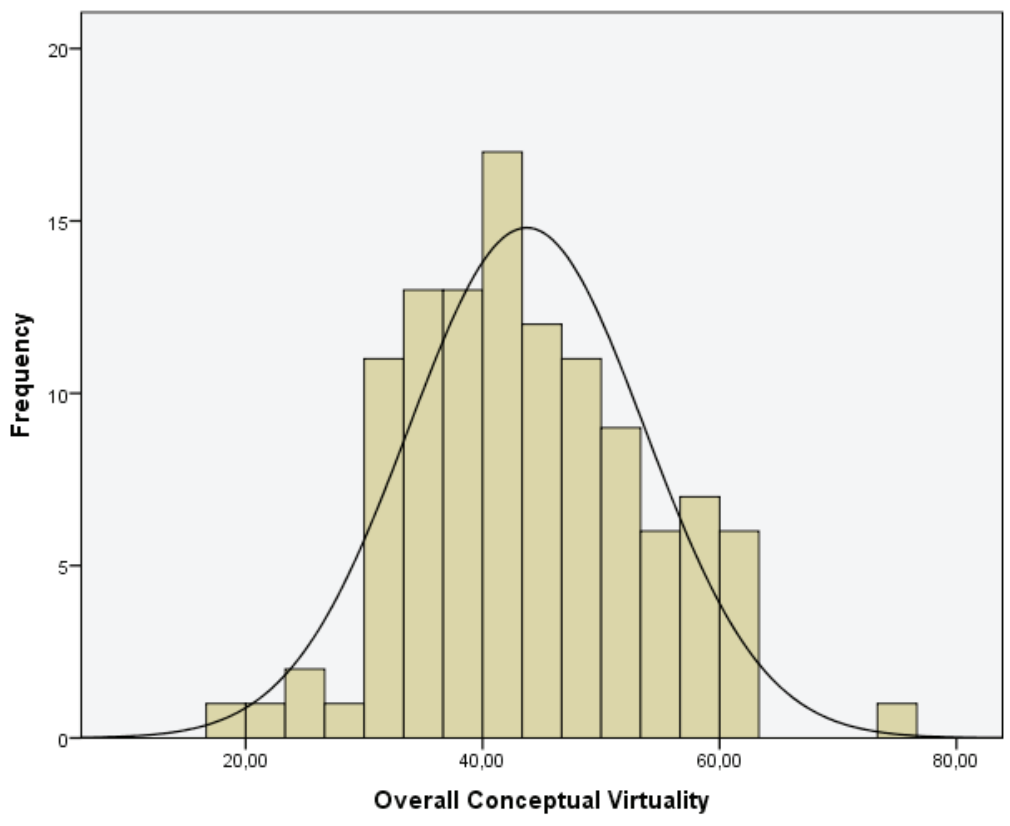

Figure 2. Distribution of participants by their overall contextual virtuality

As is seen, the distribution is almost the same as a normal distribution and this indicates that the sample used for the study is of the adequate quality to provide meaningful conclusions for the study. Skewness and kurtosis values also indicate a normal distribution $(p<0.05)$. 


\section{Results}

Analysis of the data was conducted in three steps. First the demographic and organisational data were analysed via descriptive and frequency analyses. Then the first two hypotheses were tested via variance (ANOVA) analyses. And finally the last three hypotheses were tested via regression analyses.

As the preliminary step for the analyses, first the descriptive and frequency analyses were conducted on demographic and organisational data. It was demonstrated that only $10 \%$ of the participants lived in a different city than their own city of residence. On the other hand, the average age of the sample was 35 with an intense distribution in the 20-30 age range. Participants of the sample consisted of approximately $65 \%$ males and $56 \%$ of people with bachelor's degrees. While approximately $75 \%$ of participants did not have any management roles, the organisations they work for had an almost equal distribution regarding the organisation sizes (micro, small, medium, large, very large) with a $71 \%$ majority in services sector. And finally participants most commonly worked in teams of 3-5 people (35\%).

After the descriptive and frequency analyses, variance analyses (ANOVA) were conducted to identify whether the variables IPV (Individual Propensity for Virtuality) and OCV (Overall Contextual Virtuality) varied depending on personal variables (gender, level of education, being a manager) or organisational variables (organisation size, sector, team size). As mentioned above, the hypotheses $\mathrm{H} 1$ and $\mathrm{H} 2$ were tested at this stage, results are presented below:

Table 5. Results of ANOVA tests

\begin{tabular}{|c|c|c|c|c|c|c|c|c|}
\hline \multirow{2}{*}{$\begin{array}{l}\text { Tested } \\
\text { Hypothesis }\end{array}$} & \multirow[t]{2}{*}{ Tested Variables } & \multicolumn{4}{|c|}{$\begin{array}{l}\text { Homogeneity of Variances (Levene } \\
\text { Test) }\end{array}$} & \multicolumn{2}{|c|}{$\begin{array}{l}\text { One Way } \\
\text { Variance Analysis } \\
\text { (ANOVA) }\end{array}$} & \multirow{2}{*}{$\begin{array}{l}\text { Difference } \\
\text { Between } \\
\text { Categories }\end{array}$} \\
\hline & & $\begin{array}{l}\text { Levene } \\
\text { Statistic }\end{array}$ & df1 & df2 & Sig. & $\mathbf{F}$ & Sig. & \\
\hline \multirow{3}{*}{ H1 } & OCV x Organisation size & ,438 & 4 & 106 & ,781 & ,252 & ,908 & No \\
\hline & OCV x Sector & 4,630 & 1 & 109 & ,034 &, 588 & ,445 & No \\
\hline & OCV x Team size & 1,896 & 4 & 105 & ,117 & ,245 & ,912 & No \\
\hline \multirow{6}{*}{$\mathrm{H} 2$} & IPV x Gender &, 035 & 1 & 109 & ,853 & 1,404 & ,239 & No \\
\hline & IPV $x$ Level of education & ,912 & 4 & 106 & ,460 & 947 & ,440 & No \\
\hline & IPV $x$ Being a manager & 2,676 & 1 & 109 & ,105 & , 140 & ,709 & No \\
\hline & IPV x Organisation size &, 847 & 4 & 106 & ,499 & 1,091 & ,365 & No \\
\hline & IPV $x$ Sector & ,659 & 1 & 109 & ,419 & ,244 & ,622 & No \\
\hline & IPV $x$ Team size &, 120 & 4 & 105 & ,975 & 2,166 & ,078 & No \\
\hline
\end{tabular}

As seen on the table, results for the ANOVA test indicate that there is no difference among the categories with regard to IPV and OCV variables $(p>0.05)$, therefore hypotheses $\mathrm{H} 1_{1}$ and $\mathrm{H} 2_{1}$ are rejected. 
Final and most important stage of the statistical analyses comprised of the regression analyses conducted between the overall contextual virtuality (OCV) as the dependent variable and the individual propensity for virtuality (IPV), psycho-social performance (PSP) and organisational commitment (OC) as independent variables.

Results of the regression analyses are given below together with the hypotheses tested. The generic regression module used for the analyses is as follows:

$Y=\alpha+\beta_{1} X_{1}+\beta_{2} X_{2}+\beta_{3} X_{3} \cdots$

First regression analysis was conducted to determine whether there is a significant relationship between the Overall Contextual Virtuality and employees' Individual Propensity for Virtuality. Hypothesis $\mathrm{H} 3$ was tested under this analysis.

According to the results of the tests, there is a significant relationship between the two variables $(p=0.001, p<0.05)$. Contributions of all factors are given below. While the highest $\beta$ values indicate the highest contribution, negative values indicate a negative correlation between two variables.

Table 6. Factors explaining Individual Propensity for Virtuality (IPV)

\begin{tabular}{llll}
\hline & B & SE & $\boldsymbol{\beta}$ \\
\hline (Constant) & 45.239 & 26.909 & \\
Age & -.173 & .293 & $\mathbf{- . 0 6 0}$ \\
Gender & -9.353 & 5.642 & $\mathbf{- . 1 5 4}$ \\
Level of Education & -2.551 & 1.373 & $\mathbf{- . 1 6 5}$ \\
Being a Manager & -3.157 & 6.400 & $\mathbf{- . 0 4 7}$ \\
Organisation Size & -1.459 & 2.048 & $\mathbf{- . 0 7 2}$ \\
Sector & 1.857 & 5.991 & $\mathbf{. 0 2 9}$ \\
Team Size & 1.784 & 2.164 & $\mathbf{. 0 8 2}$ \\
OCV & 1.249 & 0.270 & $\mathbf{. 4 2 8}$ \\
\hline
\end{tabular}

Second regression analysis was conducted to determine whether there is a significant relationship between the Overall Contextual Virtuality and employees' Psycho-Social Performance. Hypothesis H4 was tested under this analysis.

According to the results of the tests, there is a significant relationship between the two variables $(p=0.005, p<0.05)$. Contribution of the each variable is given below: 
Table 7. Factors explaining Psycho-Social Performance (PSP)

\begin{tabular}{llll}
\hline & B & SE & $\beta$ \\
\hline (Constant) & 69.377 & 14.659 & \\
Age & -.253 & .160 & -.166 \\
Gender & 3.930 & 3.073 &. $\mathbf{1 2 1}$ \\
Level of Education & .461 & .748 & .056 \\
Being a Manager & 4.642 & 3.487 &. $\mathbf{1 3 0}$ \\
Organisation Size & -1.047 & 1.116 & $\mathbf{- 0 9 7}$ \\
Sector & 1.006 & 3.264 &. $\mathbf{0 3 0}$ \\
Team Size & -2.034 & 1.179 & $\mathbf{- 1 7 6}$ \\
OCV & .351 & .147 &. $\mathbf{2 2 5}$ \\
\hline
\end{tabular}

Last regression analysis is conducted to determine whether there is a significant relationship between the Overall Contextual Virtuality and employees' Organisational Commitment. Hypothesis $\mathrm{H} 5$ was tested under this analysis.

According to the results of the tests, there is no significant relationship between the two variables at $95 \%$ confidence level $(p=0.075, p>0.05)$. Therefore, details of the analysis are not included in this research.

According to the results of the analysis, the $p$ values for regression analyses are below 0.05 for IPV and PSP and above 0.05 for OC. This indicates that, together with the personal and organisational variables, the overall contextual virtuality, or simply the degree of virtuality is significant in explaining the individual propensity for virtuality and psycho-social performance variables as they have $p$ values below 0.05 . However this does not apply to organisational commitment since it has a $p$ value above 0.05 . In other words, there is a significant and positive relationship between the degree of virtuality and individual propensity for virtuality as well as with psychosocial performance. On the other hand, there is no significant relationship between the degree of virtuality and organisational commitment at this confidence level of 95\%. Therefore the hypotheses $\mathrm{H}_{1}$ and $\mathrm{H}_{4}$ are accepted while $\mathrm{H} 5_{1}$ is rejected.

\section{Conclusions and Discussion}

Virtualisation is a rapidly moving concept which steadily transforms the organisation structures which have been regarded as concrete systems for decades. Technology makes it possible for organisations, employers and employees to move faster, further and stronger in the global world. Organisations benefit from opportunities in distant parts of the world to maximise their profits, employers get the chance to reach the most suitable employees regardless of their distance and employees reach a striking amount of job opportunities all around the world.

As a result of virtualisation, boundaries become obsolete and organisations become more flexible. This results in flattened organisations where middle managers responsible for supervision are removed and employees become more self-managing and qualified. Therefore organisations 
become more dynamic and responsive to the outside world. Expenses decrease as more and more employees embrace virtual work settings and enjoy the benefits of virtuality such as freedom, higher motivation and wider range of opportunities.

Since virtualisation has become a prominent concept in the business world, it also became a topic worthy of research in terms of its advantages and disadvantages. In the scope of this study, degree of virtuality of organisations as perceived by their employees was addressed and its effects on individual propensity for virtuality, psycho-social performance and organisational commitment were investigated. As a result, the following conclusions were drawn:

1. Degree of virtuality does not vary depending on the organisational variables (organisation size, sector, team size).

2. Employees' individual propensity for virtuality does not vary depending on demographic variables (age, gender, level of education, being a manager) and organisational variables (organisation size, sector, team size).

3. Together with demographic and organisational variables, there is a positive relationship between the degree of virtuality and employees' individual propensity for virtuality. In other words, virtual workers are satisfied with the structure they work in and are willing to continue to work the same way.

4. Together with demographic and organisational variables, there is a positive relationship between the degree of virtuality and employees' psycho-social performance. In other words, as organisations become more virtual, the psycho-social performance of employees also increases.

5. Together with demographic and organisational variables, no significant relationship has been found between the degree of virtuality and employees' organisational commitment. In other words, there is no connection made between the degree of virtuality and commitment of employees to their organisations.

In comparison to the research by Schmidt et. al. (2008), which constituted the basis for this study, results show similar conclusions. While in their study, the psycho-social performance variable was examined under three dimensions and two out of them were found to have a significant relationship with virtuality; in this study these dimensions were considered in a holistic approach under one variable and it was concluded that virtuality has a significant impact on this variable. This conclusion also supports the results of the studies conducted by Merkevicius and UturyteVrubliauskiene (2008), Oflazer Mirap (2004), Afgün (2006) and Wiesenfeld et. al.(1999). On the other hand, it is concluded that degree of virtuality is positively related to individual propensity for virtuality. This also supports the other abovementioned research on work satisfaction (Webster and Wong, 2008; TinyPulse, 2015), communication among employees (Akkirman and Harris, 2005) and work coherence (Afgün, 2006) which all affect employees' willingness to continue working in virtual organisational structures. 
As for the organisational commitment variable, the amount of research in the literature which indicate a significant relationship between this variable and virtuality overweighs the ones that indicate the opposite (Golden and Veiga, 2008; Golden, 2006; Burman and Shastri, 2013). However, on the contrary, this study has come to the conclusion that there is no significant relationship between these two variables. Considering the fact that organisational commitment is a complex and subjective concept which can be affected by many factors, this incoherence is understandable. Still, more research should be conducted on the matter to more clearly determine the roots of organisational commitment.

In conclusion, this study investigated the concept of virtuality in relation with psycho-social performance and organisational commitment. It reached a significant finding that virtuality effects psycho-social performance in a positive manner. Also the sub-scale for individual propensity for virtuality points out that virtual workers are satisfied with their working conditions, which is also an important conclusion for both employers and employees. Virtual organisation structures can provide remarkable benefits for developing countries such as Turkey with young populations, where people can be trained in such occupations with higher added value such as ICT. Therefore organisations and employees are recommended to be open for new developments and overcome their prejudice in order to benefit from such opportunities.

Overall, results of this study provide useful insight, although not claiming to be exhaustive. Hopefully it can inspire other researchers to conduct studies in this developing field and raise awareness on the opportunities that can be seized by allowing virtuality in all organisation types.

\section{References}

Afgün, S. (2006). Sanal organizasyonlarda yapı, yönetim ve iletişim. (Unpublished Master’s Thesis). Atatürk University, Erzurum.

Ahuja, M. K. and Carley, K. M. (1998). Network structure in virtual organizations. Retrieved from jcmc. indiana.edu/vol3/issue4/ahuja.html. [Accessed 5 April 2016].

Akkirman, A. D. and Harris, D. L. (2005). Organizational communication satisfaction in the virtual workplace. The Journal of Management Development, 24(5/6), 397-409.

Benton, D. A. (2012). The virtual executive: how to act like a CEO online and offline. New York: McGrawHill.

Burman, S. and Shastri, S. (2013). Occupational stress and organizational commitment of employees in virtual and traditional teams: a comparative study. International Journal of Science and Research, 2(10), 100-106.

Daniels, K., Lamond, D. and Standen, P. (2001). Teleworking: Frameworks for organizational research. Journal of Management Studies, 38(8), 1151-1185.

Fulk, J. and Desanctis, G. (1995). Electronic communication and changing organizational forms. Organization Science, 6(4), 337-349.

Garton, C. and Wegryn, K. (2006). Managing without walls: maximize success with virtual, global, and cross-cultural teams. Lewisville, TX: MC Press. 
Golden, T. D. (2006). Avoiding depletion in virtual work: telework and the intervening impact of work exhaustion on commitment and turnover intentions. Journal of Vocational Behavior, 69, 176-187.

Golden, T. D. and Veiga, J. F. (2008). The impact of superior-subordinate relationships on the commitment, job satisfaction, and performance of virtual workers. The Leadership Quarterly, 19, 77-88.

Kırel, Ç. (2007). Sanal örgütlerde örgütsel davranışın geleceği. Anadolu Üniversitesi Sosyal Bilimler Dergisi, 1, 93-110.

Lojeski, K. S. and Reilly, R. R. (2010). Leading the virtual workforce: how great leaders transform organizations in the 21st century. Hoboken, NJ: Wiley.

Merkevicius, J. and Uturyte-Vrubliauskiene, L. (2008). Virtual and traditional organizations: singularity of personnel motivation. Social Research, 3(13), 589-595.

Meyer, J. P., Allen, N. J. and Smith, C. A. (1993). Commitment to organizations and occupations: extension and test of a three-component conceptualization. Journal of Applied Psychology, 78(4), 538-551.

Norton, B. and Smith, C. (1997). Understanding the virtual organization. Hauppauge, NY: Barron's Educational Series.

Oflazer Mirap, S. (2004). Sanal organizasyonlar ve sanal organizasyonlarda çalışanların motivasyonu ve iletişimi üzerine bir uygulama. (Unpublished Master’s Thesis). Erciyes University, Kayseri.

Schmidt, C., Temple, B.K., McCready A., Newman J. and Kinzler S.C. (2008). Virtuality in organizational team environments: concept, measurement and effects in the context of sustainable management. In N. Panteli and M. Chiasson (Eds). Exploring virtuality within and beyond organizations: social, global, and local dimensions. Houndmills, Basingstoke, Hampshire: Palgrave Macmillan.

Soper, D.S. (2016). A-priori sample size calculator for multiple regression. http://www.danielsoper.com/ statcalc (Accessed on: 14.10.2016)

TinyPulse. (2015) What leaders need to know about remote workers. https://cdn2.hubspot.net/hubfs/443262/ TINYpulse_What_Leaders_Need_to_Know_About_Remote_Workers.pdf?t=1462203875281 [Accessed 29 April 2016].

Toglaw, S. D. (2006). Organizational commitment in a virtual work environment. (Unpublished Master's Thesis).. Sidney: University of Technology.

Warner, M. and Witzel, M. (2004). Managing in virtual organizations. London: Thomson Learning.

Webster, J. and Wong, W. P. (2008). Comparing traditional and virtual group forms: identity, communication and trust in naturally occurring project teams. The International Journal of Human Resource Management, 19(1), 41-62.

Wiesenfeld, B. M., Raghuram, S. and Garud, R. (1999). Communication patterns as determinants of organizational identification in a virtual organization. Organization Science, 10(6), 777-790. 
